\title{
ECONOMIC CHARACTERISTICS OF SOUR CREAM PRODUCTION IN SMALL-SCALE DAIRY PROCESSORS IN SERBIA
}

Dragan Milić1 , Danica Glavaš-Trbić2, Mirela Tomaš Simin ${ }^{3}$, Vladislav Zekić4, Tihomir Novakovićs ${ }^{5}$ Milana Popov ${ }^{6}$

*Corresponding authorE-mail: danicagt@polj.uns.ac.rs

\begin{abstract}
A R T I C LE IN F O
A B S T R A C T

Original Article

In Serbia small family households dominate in milk

Received: 13 August2019 production, while large-scale capacity dairies dominate in milk processing. There are over 200 dairy processing Accepted: 16 September 2019 doi:10.5937/ekoPolj1903787M

UDC 33:634.63(497.11) plants, and currently they manufacture about $80 \%$ of all dairy products. In this race small-scale dairies are lagging behind. The aim of this paper is to investigate economic characteristics of processing milk into sour cream in small-

Keywords:

sour cream, small-scale dairy processors, dairy industry, competitiveness, production costs

JEL: $Q 10, Q 12$ scale dairy processors in Serbia. The research showed that the cost price of sour cream with a minimum of $20 \%$ milk fat is $68.96 \mathrm{RSD} / \mathrm{kg}$. The largest share in total costs has costs of raw material accout for $44.11 \%$ and labor costs for $38.79 \%$, while the remaining costs are packaging, transport and other overheads. In order for small-scale capacity dairies to compete with larger-scale capacity dairies, both in product quality and price, it is necessary to continuously monitor and minimize production costs.
\end{abstract}

(C) 2019 EA. All rights reserved.

1 Dragan Milić, PhD, Assistant Professor, University of Novi Sad, Faculty of Agriculture, Trg Dositeja Obradovića 8, 21000 Novi Sad, Serbia, Phone: +381 21 4853274, E-mail: dragan. milic@polj.edu.rs, http://orcid.org/0000-0003-0377-1540

2 Danica Glavaš - Trbić, M.Sc., Teaching Assistant, University of Novi Sad, Faculty of Agriculture, Trg Dositeja Obradovića 8, 21000 Novi Sad, Serbia, Phone: +381 214853508 , E-mail: danicagt@polj.uns.ac.rs, http://orcid.org/0000-0002-5990-6558

3 Mirela Tomaš Simin, PhD, Teaching Assistant, University of Novi Sad, Faculty of Agriculture, Trg Dositeja Obradovića 8, 21000 Novi Sad, Serbia, Phone: +381 214853514 , E-mail: mirelat@polj.uns.ac.rs, http://orcid.org/0000-0003-1833-9857

4 Vladislav Zekić, PhD, Full Professor, University of Novi Sad, Faculty of Agriculture, Trg Dositeja Obradovića 8, 21000 Novi Sad, Serbia, Phone: +381 21 4853510, E-mail: zekic@ polj.uns.ac.rs, https://orcid.org/0000-0002-7377-2402

5 Tihomir Novaković, Mmgt, Teaching Assistant, University of Novi Sad, Faculty of Agriculture, Trg Dositeja Obradovića 8, 21000 Novi Sad, Serbia, Phone: +381 21 4853307, E-mail: tihomir.novakovic@polj.uns.ac.rs, http://orcid.org/0000-0002-8405-3403

6 Milana Popov, M.Sc., Teaching Assistant, University of Novi Sad, Faculty of Agriculture, Trg Dositeja Obradovića 8, 21000 Novi Sad, Serbia, E-mail: milana.popov@gmail.com, http://orcid.org/0000-0003-2633-5661

http://ea.bg.ac.rs 


\section{Introduction}

Milk and meat are the most important products of cattle production and are of great importance in human nutrition. Milk is recognized as an important source of energy, high-quality protein and essentail minerals as well as vitamins (Paszczyk et al., 2019). Dairy products cannot be substituted in human nutrition. Milk as a source of nutrition is especially important for infants and children, who need nutrient and energy rich food for growth and cognitive development (Garcia et al., 2019). Cattle consumer milk is prevalent at the market in terms of the produced and placed amount, relative to goat's and sheep's milk. The production of goat's milk and milk products has been gaining in importance in recent years as a result of recognizing the role of goat's milk in human nutrition from a health perspective (Popović Vranješ et al., 2017). Developed countries in the world record higher consumption of dairy products. In the same time, less developed countries are dominated by consumption of drinking milk, due to lower prices, lower incomes and lower living standards. The development of processing can significantly affect the overall growth rate of agricultural production and increase the total income of the agro-industrial sector (Zekić et al., 2016). Some of the milk products and semi-finalized products that can be obtained from processing plants are fresh soft and grain cheeses, semi-hard and hard cheeses, yogurt, sour milk, whey, butter, milk powder and kefir.

In the foreign trade of milk and milk products, Serbia has a positive balance and is one of the leading countries in this production in the region (Veljković et al., 2015). Cheese is considered to be the most perspective product in terms of production, marketing and export, but the potential and importance of other milk products should not be diminished. Cheese production in Serbia varies annually, with an average of about 55 thousand tons which is likely to increase (Eurostat, 2019), and according to the data of the Statistical Office of the Republic of Serbia, around 27 thousand tons of cow's milk sour cream is produced annually. This indicates that other dairy products should not be neglected. Serbia exports products with low degree of processing and less value added than imported products (Veljković et al., 2015), which makes it less competitive in the international market.

There are currently more than 200 registered dairy processing plants in Serbia (Vlahović et al., 2018), which can be classified into three groups by annual production: large, medium and small. Milk is by $2 / 3$ processing in dairy plants while significant amount still used and processed on farms (Popović and Panić, 2018). In Serbia milk processing facilities are largely concentrated in a few milk processing companies. These companies participate at about $90 \%$ in total milk processing, which means that they dominate the market (Jakšić et al., 2015). Smaller milk producers, who cannot apply for state support, only cooperate with small-scale capacity dairies and thus manage to survive on the market because they are not recognized by large-scale dairies. The advantage of small and medium-sized manufacturers is that they can respond to demand change and fluctuations with an adequate range of products within a short period of time (Popović Vranješ et al., 2017). Only large-scale farmers, who have better quality milk, are 
eligible for state support, have higher production volumes, modern and more efficient production technology, can continuously respond to market needs, cooperate with large dairies. Production of large processing capacities is mostly oriented toward liquid dairy products, while cheese production is mainly of less priority (Zekić et al., 2016). Smallscale and medium-scale capacity dairies mainly process milk into cheese, yogurt, kefir, sour cream and the like. At the same time, the consumption of dairy products has recently been marked by the demand for traditional products, that is, products with a certain geographical origin, come from small farms and represent for consumers the synonymous of "healthy" food (Popović Vranješ et al., 2017).

Increase of competitiveness may be based on different elements: product prices, costs of production, new technology, innovation, knowledge, human resources, entrepreneurship, the brand and the quality of the product, etc. (Glavaš-Trbić and Maksimović, 2013). Dairies have to decide on the type of products to be processed, from pasteurized milk to more sophisticated dairy products such as cheese, yogurt and icecream. Processing costs, inputs and output costs and milk quality may become critical aspects that influence the decision on how they can respond to market opportunities (Fuentes et al., 2016). In order to survive in the race with large dairies, small dairies strive to improve their organization, make better use of existing capacities, choose the right product range, maintain quality levels, reduce production costs and increase prices

and volume of dairy products. Only dairies that are qualitatively and cost-competitive with their products and able to meet quality standards and export their products can survive on the market (Veljković et al., 2015).

The authors analyze the economic characteristics of small-scale capacity dairy processors in Serbia in the production of sour cream. In order to make dairy products more cost efficient, cost effective and competitive in the foreign market, it is necessary to monitor and improve all aspects of their business. This is especially important for small-scale capacity dairies, which, in terms of performance, lag behind medium and large dairies in Serbia.

\section{Materials and methods}

Based on the financial analysis of a representative small-scale dairy producer in Serbia, this paper aims to investigate economic characteristics of processing milk into sour cream in small-scale processors. The aim of the paper is to calculate cost price taking into account milk processing costs required to produce cour cream with minimum of $20 \%$ milk fat and to discover how and to what extent these costs affect the operation of small-scale processors.

To determine the level and structure of production costs of dairy products, the analytical calculation method of per unit processing costs has been used (Marko et al., 1998), that is, costs have been calculated per kilogram of dairy product produced. The purpose of the calculation is to account the cost price of individual products, as well as to create an information basis for controlling them and evaluating the cost-effectiveness of the 
business (Zekić et al., 2015). The economic analysis of milk processing costs required to produce sour cream with minimum of $20 \%$ milk fat includes the direct material costs (the cost of raw materials, packaging and labelling), depreciation costs, labor costs (wages) and transport costs.

The analysis is based on the total cost of processing milk into sour cream, which is made up of fixed and variable cost, as expressed in the equation below (Marko et al., 1998):

$$
\mathrm{TC}=\mathrm{FC}+\mathrm{VC}
$$

where:

$\mathrm{TC}=$ Total Cost,

$\mathrm{FC}=$ Fixed Cost, and

$\mathrm{VC}=$ Variable Cost.

After the calculation of total and individual costs, per unit processing cost is determined. The aim of determining the cost price is to burden each product with the amount of costs that its production has made (Zekić et al., 2015).

To ascertain the share of particular cost in one kilogram of dairy products, it is necessary to divide the total cost by quantity (total product), as shown in the equation below:

$$
\mathrm{CP}=\mathrm{TC} / \mathrm{Q}
$$

where:

$\mathrm{CP}=$ per unit cost or Cost Price,

$\mathrm{TC}=$ Total Cost, and

$\mathrm{Q}=$ Quantity (total product).

The study includes an analysis of economic characteristics of sour cream production in a small-scale dairy in the period from 2014 to 2016 . The data on production features of small-scale dairies is collected through field research, while the analysis of conditions in the milk sector in Serbia is based on the official data and publications of The Statistical Office of the Republic of Serbia and Euro statistics.

\section{Results with Discussions}

\section{Sour cream characteristics}

The sour cream is made of skimmed fresh milk. It is rich in fats and is therefore a very high calorie food, but it is still an easily digestible food, which is used in the diet of consumers. The action of lactic acid bacteria that cause milk acidification is also used in sour cream production. Depending on the degree of acidity, it differs: sweet cream, which is usually produced with about $24 \%$ milk fat and which is collected before acidification begins; sour cream (10 to $20 \%$ milk fat), which is collected in the advanced acidification phase. 


\section{Sour cream production costs}

The economic result in sour cream production depends on market prices, on the one hand, and production costs on the other. Dairy producers can influence the costs and cost price of their own products to improve business results. Having this in mind, it is necessary to analyze the amount of costs, their structure and the effect on the production process. Cutting unnecessary costs leads to a lower cost price, which in turn increases the difference between the selling price of own product and its cost price, thus raising the profit. To determine the structure of cost price of processing milk into sour cream with minimum of $20 \%$ milk fat in the observed period, the following costs have been analyzed: direct material costs (manifested as the cost of raw materials and packaging), transport costs, labor costs (wages), depreciation costs, and other overhead costs.

The cost of raw material. Basic materials used in sour cream production are raw materials for the manufacturing (milk and other raw materials) and materials used for packaging and labelling. The amount of all raw materials in the manufacture of sour cream is defined in the recipe used by the dairy plant which is observed in this study, and the prices of dairy products are calculated on the basis of their purchase price in 2016 (Table 1). The total cost of raw materials of sour cream with a minimum $20 \%$ milk fat amounts to $30.421,60 \mathrm{RSD}$ per $1000 \mathrm{~kg}$. The cost per one kilogram of the product is 30.42 RSD. The share of the cost of raw materials in the total cost of the production of sour cream with a minimum of $20 \%$ milk fat is shown in Figure 1.

Figure 1. The share of the cost of raw materials in the total production cost of sour cream

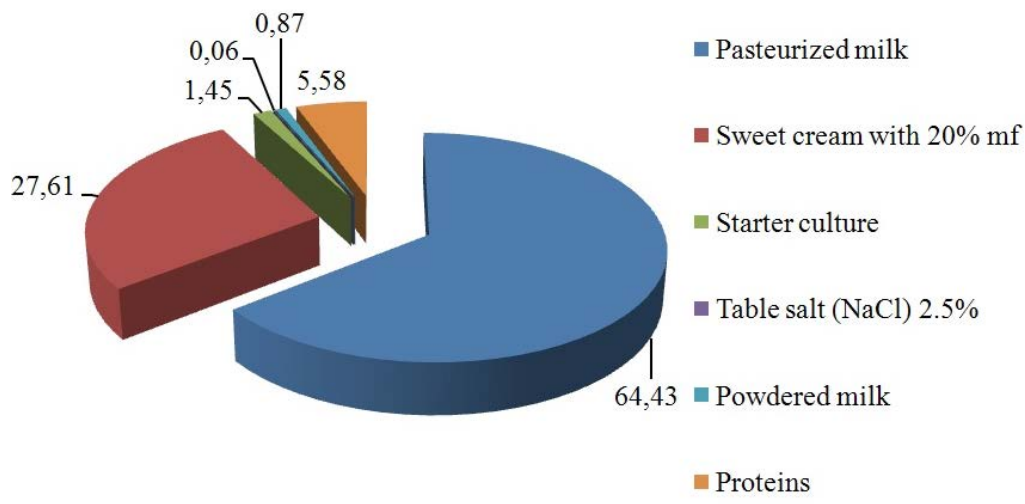

Source: Authors' calculation

As the Figure above demonstrate, the cost of pasteurized milk has the largest share in the total cost of raw materials used for the production of sour cream with a minimum of $20 \%$ milk fat, amounting to $64.43 \%$, followed by sweet cream with $27.61 \%$, meaning that milk substantialy contributes to total production costs. In addition to this, components which can influence the price of dairy products are starter cultures, salt, calcium chloride and powdered milk. The share of starter cultures in dairy products is $1.45 \%$. 
The amount of milk used varies, depending on the particular dairy product which is manufactured. The production of sour cream requires 0.7 litres of. The change in the cost of raw materials used to manufacture the product will have an impact on the final cost of the product, and therein lies the particularity of the production and costs, because every product consists of a number of components all of which have their market value. As stated earlier, milk is the raw material which makes up the largest share in the structure of any dairy product, and the increase of the market price of milk will lead to the increase of the price of dairy products. Farmgate milk prices for the analyzed period vary from 23.50 to 38.00 RSD. An overview of the prices of milk and dairy product over the three-year period is shown in the following table.

Table 1. An overview of prices of milk and dairy product in the period $2014-2016$ (RSD)

\begin{tabular}{|l|c|c|c|c|c|c|}
\hline Year & \multicolumn{2}{|c|}{$\mathbf{2 0 1 4}$} & \multicolumn{2}{c|}{2015} & \multicolumn{2}{c|}{2016} \\
\hline $\begin{array}{l}\text { Product } \\
\text { Name }\end{array}$ & $\begin{array}{c}\text { Product } \\
\text { price }\end{array}$ & $\begin{array}{c}\text { Average } \\
\text { milk price }\end{array}$ & $\begin{array}{c}\text { Product } \\
\text { price }\end{array}$ & $\begin{array}{c}\text { Average } \\
\text { milk price }\end{array}$ & $\begin{array}{c}\text { Product } \\
\text { price }\end{array}$ & $\begin{array}{c}\text { Average } \\
\text { milk price }\end{array}$ \\
\hline $\begin{array}{l}\text { Sour } \\
\text { cream with } \\
\text { minimum of } \\
\mathbf{2 0 \%} \text { milk fat }\end{array}$ & 29,75 & 27,33 & 30,07 & 27,65 & 30,42 & 28,00 \\
\hline
\end{tabular}

Source: Authors' calculation

The figures in Table 1 lead to the conclusion that the milk price did not significantly change in the period from 2014 to 2016, and therefore did not cause either an increase or decrease of the final and selling price of given dairy products in those years.

If the average price of milk of 28.00 RSD in 2016 increased by 1 RSD (for $3.57 \%$ ), with no change in prices of other raw materials, it is possible to determine the impact of the milk price on the production cost of dairy products.

Table 2. The impact of the change of the price of milk as a raw material on the price of sour cream

\begin{tabular}{|l|c|c|c|c|}
\hline $\begin{array}{l}\text { Name of dairy } \\
\text { product }\end{array}$ & $\begin{array}{c}\text { Amount of } \\
\text { milk in dairy } \\
\text { products } \\
\text { (I) }\end{array}$ & $\begin{array}{c}\text { Price of dairy } \\
\text { products in } \\
\text { 2016. } \\
\text { (RSD/kg) }\end{array}$ & $\begin{array}{c}\text { Price of dairy } \\
\text { products after } \\
\text { the price of milk } \\
\text { increased for 3.57\% } \\
\text { (RSD/kg) }\end{array}$ & $\begin{array}{c}\text { The difference } \\
\text { in price after } \\
\text { the increase } \\
\text { (RSD) }\end{array}$ \\
\hline $\begin{array}{l}\text { Sour cream with } \\
\text { minimum of 20\% } \\
\text { milk fat }\end{array}$ & 0,7 & 30,42 & 31,12 & 0,7 \\
\hline
\end{tabular}

Source: Authors' calculation

The figures in Table 2 show that every increase of the price of milk leads to an increase of the price of dairy products. In this case, the price of sour cream with a minimum of $20 \%$ milk fat increases for 0.7 RSD per kilogram, which is a $2.3 \%$ increase. An increase of the price of any other raw material does not lead to a significant increase of the price of dairy products, as the increase of the milk price does, because their share is considerably smaller than that of milk. 
The cost of packaging and labelling. The second significant material cost is the cost of packaging. Packaging is a very important object for innovation activities because it has safety, handling, information and sales functions (Špička et al., 2015). Packaging of dairy products develops continuously along with advances in material technologies, which are in turn a response to demands of consumers (Ščetar et al., 2018). The process, method and material for packaging in a dairy is different depending on the product being packaged. Dairies try to use new packages which protect the contents, extend the life of milk products, attract consumers, and make the contents easy to store and transport. In addition, new packages are also environmental-friendly (Špička et al., 2015).

Sour cream comes in packing of $180 \mathrm{~g}$ and $400 \mathrm{~kg}$ and it is packaged in cups. In addition to packaging, the cost of labelling has to be taken into account. The cost of one printed label depends on the type of print, paper, size and the like. The declaration for sour cream cups is printed on the cover itself, and the purchase price of one such cover is 0.74 RSD for small cups and 1.25 RSD for large cups. Small cups (180 g) for sour cream are purchased at the price of $1.63 \mathrm{RSD}$, while for large cups $(400 \mathrm{~g})$ this price is 3.65 RSD. In addition, covers are an element of the costs that are included in the final product, i.e. their packaging. Table 3 shows the cost of packaging and labelling.

Table 3. The cost of packaging and labelling of sour cream

\begin{tabular}{|l|c|c|}
\hline Packaging and labelling & Purchase price [RSD] & Share in the total price [\%] \\
\hline \multicolumn{3}{|c|}{ Sour cream 180 g 20 \% mf } \\
\hline Cup & 1,63 & 4,79 \\
\hline Cover with declaration & 0,74 & 2,17 \\
\hline \multicolumn{3}{|c|}{ Sour cream 400 g 20 \% mf } \\
\hline Cup & 3,65 & 4,86 \\
\hline Cover with declaration & 1,25 & 1,66 \\
\hline
\end{tabular}

Source: Authors' calculation

According to previous Table costs of packaging and labelling have the largest share in the production of $400 \mathrm{~g}$ cups of cour cream and amount of $4.86 \%$.

Transport costs. When calculating the total cost, transport costs have to be included as one of the elements, and they consist of all activities performed in the transportation process, starting from the place where goods are loaded and ending at the place where goods are unloaded. Transport costs can differ depending on the type of goods, type of transport, quantity of goods, and the final destination. Milk and dairy products can be shipped using own transport or that of the seller or producer, hiring a third party, and using the buyer's transport. The place of delivery can be the buyer's address, a place previously agreed upon, or goods can be collected directly from the dairy plant. Depending on the aforementioned variables, the cost price will vary. If the goods are delivered to the buyer, transport costs increase as the distance increases from the place of loading (dairy plant) to the place of delivery, that is the place of unloading. In the dairy plant which is analyzed in this paper, the calcualtion assumes that the transportation is conducted by the dairy's own transport vehicles of 3.5 tons of payload capacity. In this 
dairy, transport costs amount to about $4.06 \%$, or 2.80 RSD per kilogram of produced sour cream, and they mainly depend on the location of the delivery and the cost of fuel, which means that they change with the mileage and quantity. It is fuel that is generally the most important factor influencing transport costs in case of own transport. Costs of vehicle purchase and maintenance are included in depreciation costs. Considering high fuel prices and the distance, transport costs can lead to a considerable increase of the cost of the finished product. Therefore, payload of the vehicle should be utilized to the highest degree to make the production more economical.

Labor costs (wages). Labor costs represent a considerable portion of any company's total costs. While calculating average gross wages and total monthly labor costs, the distinction was made between employees who work in administration and those who work in production, and what their qualifications are, as gross wages of individual workers depend on these factors. Dividing monthly labor costs by montly volume of production gives the share of gross wages in 1 litre or, in this case, 1 kilogram of dairy products over the period of one month. Applying the calculation to a working day gives the same results. In the analyzed period, an average share of gross wages is 37.26 $\mathrm{RSD} / 1$ or $26.75 \mathrm{RSD} / \mathrm{kg}$ of dairy product.

Overhead costs. Manufacturing overhead costs of sour cream constitute about 5.93\% of total costs, and they consist of depreciation costs, costs of telecommunications services, power costs, travelling expenses, indirect material costs, legal and contractual obligations, stationery, working equipment for workers and other small material costs. Calculated on the annual level and per kilogram, these costs amount to 4.09 RSD. These costs do not have a direct impact on the final product, but they surely do have an impact on this line of production in the form of overhead costs.

Labor costs and overhead costs are relatively constant and they do not fluctuate considerably. Generally speaking, the high degree of dependence between capacity utilization rate and financial result comes from the existence of fixed costs and their change, both in absolute amount and per unit of product. These costs are also significant in the case of small-scale capacity plants (Zekić et al., 2016).

\section{The structure of cost price of sour cream}

Based on the above mentioned production costs, that is the cost of processing milk into sour cream, it is possible to determine the structure and amount of the cost price for the analyzed products, as shown in Table 4.

Table 4. The structure of cost price of sour cream

\begin{tabular}{|c|l|c|c|}
\hline & Costs & $\begin{array}{c}\text { Sour cream with minimum of 20\% milk } \\
\text { fat } \\
\text { (RSD/kg) }\end{array}$ & $\begin{array}{c}\text { Share } \\
(\mathbf{\%})\end{array}$ \\
\hline 1 & Raw materials & 30,42 & 44,11 \\
\hline 2 & Transportation & 2,80 & 4,06 \\
\hline 3 & Packaging & 4,90 & 7,10 \\
\hline
\end{tabular}




\begin{tabular}{|c|l|c|c|}
\hline Costs & $\begin{array}{c}\text { Sour cream with minimum of 20\% milk } \\
\text { fat } \\
(\mathbf{R S D} / \mathbf{k g})\end{array}$ & $\begin{array}{c}\text { Share } \\
\mathbf{( \% )}\end{array}$ \\
\hline 4 & Labor costs & 26,75 & 38,79 \\
\hline 5 & Overhead costs & 4,09 & 5,94 \\
\hline & Total: & $\mathbf{6 8 , 9 6}$ & $\mathbf{1 0 0}$ \\
\hline
\end{tabular}

Source: Authors' calculation

As the figures in Table 4 show, production costs of 1 kilogram of sour cream are 68,96 $\mathrm{RSD} / \mathrm{kg}$ without the VAT. Figure 2 shows the structure of individual costs in total production costs of this milk product.

Figure 2. The structure of individual costs in total costs of sour cream production

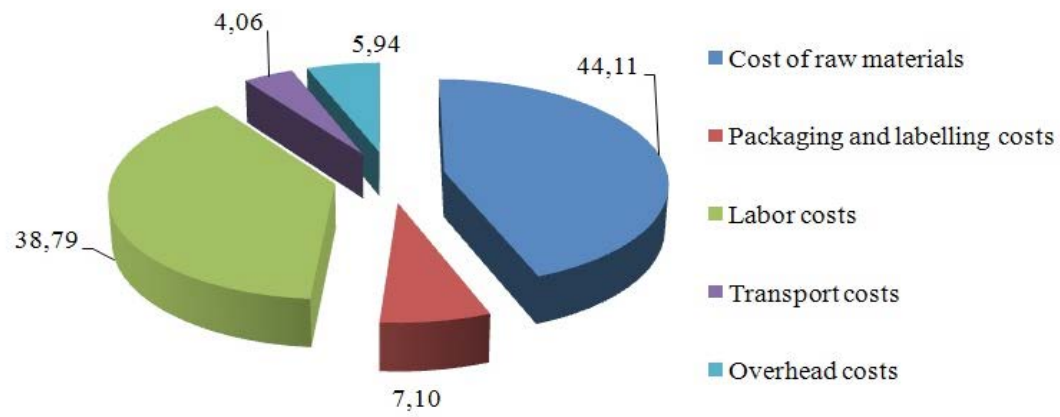

Source: Authors' calculation

The costs of raw materials for the production of sour cream have the largest share and amount to $44.11 \%$. This is because raw materials are substances which make up the product, and together with the costs of packaging and labelling constitute the main product. In terms of the amount and significance, the cost of raw materials is followed by labor costs of $38.79 \%$, packaging cost of $7.10 \%$, overhead costs of $5.93 \%$ and transport costs of $4.06 \%$. Considering all of this, in order to remain competitive in the market, a small-scale dairy processing plant should pay utmost attention to direct material costs and purchase raw materials at lower prices without sacrificing their quality and ultimately the quality of dairy products.

\section{Conclusions}

The production, processing and sale of milk and dairy products is one of the significant segments of the agribusiness sector in Serbia. Dairy processing is dominated by largescale capacity dairies. The number of small-scale capacity dairies is increasing in the http://ea.bg.ac.rs 
market, with about $20 \%$ of the total milk processing in Serbia. If small-scale capacity dairies fail to achieve qualitative and cost competitiveness, meet consumer needs, meet quality standards, increase exports to European Union countries and beyond, the expansion of production capacity, reduced numbers of smaller dairies and their vertical integration can be expected. In order for small-scale capacity dairies to compete with larger-scale capacity dairies, both in product quality and price, it is necessary to continuously monitor and minimize production costs. In addition to cheese, which is considered to be the most promising dairy product in terms of production and export, other dairy products, which could improve the economic position of dairies of all capacities, should also be pay attention.

The study has revealed that cost price of sour cream with a minimum of $20 \%$ milk fat in a small-scale dairy processor amounts to $68.96 \mathrm{RSD} / \mathrm{kg}$. As the results show, processing milk into sour cream is justifiable, when compared with the sales of raw milk. Thereby, care should be taken of the cost structure that determines the cost of the final product and how to reduce these costs without compromising the quality of the product itself. With $44.11 \%$ in the structure of total costs of processing milk into sour cream, the cost of raw materials has the largest share because they are substances which final products are made of. The component which has a significant impact on the price of the dairy product is the price of milk, while an increase of prices of other raw materials does not have as significant an impact on the price of dairy products as raw milk does, because they have a much smaller share in total costs. In the total costs, labor costs involve $38.79 \%$, which is the second highest cost after raw materials. The level of these costs directly depends on the number of employees, working hours and wages as well as the volume of monthly production. The primary principle of reduction of these costs is to purchase modern machinery and equipment, which minimizes the number of employees. The costs of packaging and labelling are designated as direct material costs and they participate with $7.10 \%$ in the cost price of sour cream with a minimum of $20 \%$ milk fat. The level of these costs chiefly depends on the type and quantity of materials used for packaging. Transport costs participate with $4.06 \%$, or 2.80 RSD $/ \mathrm{kg}$ of sour cream. Payload of the vehicle should be utilized to the highest degree to make the production more economical. Manufacturing overhead costs of sour cream constitute $5.94 \%$ of total costs.

In order for small-scale dairy processors to become as competitive as large-scale ones in contemporary market conditions, they should pay utmost attention to direct material costs and purchase raw materials at lower prices without sacrificing their quality and ultimately the quality of dairy products.

\section{Acknowledgements}

Paper is part of the research within the projects TR31095 - Production of hard cheese with added value from milk produced in organic and self-sustaining systems and III 46006 - Sustainable agriculture and rural development in the function of accomplishing strategic goals of the Republic of Serbia in the Danube Region, financed by the Ministry 
of Education, Science and Technological Development of Republic of Serbia. Project period is 2011-2019.

\section{Conflict of interests}

The authors declare no conflict of interest.

\section{References}

1. European statistics (EUROSTAT), Electronic database, Retrieved from https:// ec.europa.eu/eurostat/ (July 07, 2019).

2. Fuentes, E., Bogue, J., Gomez, C., Vargas, J., Le Gal, P.Y. (2016): Supporting smallscale dairy plants in selecting market opportunities and milk payment systems using a spreadsheet model. Computers and Electronics in Agriculture, 122, 191-199.

3. Garcia, S.N., Osburn, B.I., Cullor, J.S. (2019): A one health perspective on dairy production and dairy food safety. One Health, 7.

4. Glavaš - Trbić, D., Maksimović, G. (2013). Factors of agribusiness competitiveness of the Republic of Serbia. International Scientific Conference , Sustainable Agriculture and Rural Development in Terms of the Republic of Serbia Strategic Goals Realization within the Danube Region-achievingregional competitiveness ", Thematic Proceedings, December 5-7 2013, Topola, Institute of Agricultural Economics, Belgrade, Serbia, pp.141-157.

5. Jakšić, D., Mijić, K., Zekić, S., Poljašević, J. (2015). Comparative profitability analysis of milk production companies to milk processing companies in Serbia. Custose@gronegovion on line,11(3),206-226.

6. Marko, J., Jovanović, M, Tica, N. (1998). Calculations in agriculture. University of Novi Sad, Faculty of Agriculture, Novi Sad. [in Serbian: Marko, J., Jovanović, M, Tica, N. (1998). Kalkulacije u poljoprivredi].

7. Paszczyk, B., Tonska, E., Luczynska, J (2019): Health-promoting value of cow, sheep and goat milk and yogurts. Mljekarstvo, 69(3), 182-192.

8. Popović Vranješ, A., Krstović, S., Jurakić, Ž., Popović, M., Šaran, M., Vlahović, B. (2017). Models of small cheese producing plants. Agroeconomics, 46(76), 67-78. [in Serbian: Popović Vranješ, A., Krstović, S., Jurakić, Ž., Popović, M., Šaran, M., Vlahović, B. (2017). Modeli malih pogona za proizvodnju sira].

9. Popović, R., Panić, D. (2018). Technical efficiencyof Serbian dairy processing industry. Economics of Agriculture, 65(2), 569-581.

10. Ščetar, M., Barukčić, I., Kurek, M., Jakopović, K.L., Božanić, R., Galić, K. (2018). Packaging perspective of milk and dairy products. Mljekarstvo, 69(1), 3-20.

11. Špička, J., Sumtka, L., Selby, R. (2015). Recent areas of innovation activities in the Czech dairy industry. Agri.Econ, 61(6), 249-264.

12. The Statistical Office of the Republic of Serbia, Electronic database, Retrieved from www.stat.gov.rs, (July 04, 2019). 
13. Veljković, B., Koprivica, R., Radivojević, D., Mileusnić, Z. (2015). Milk and dairy products in the foreign trade balance of Serbia. Agroeconomics, 44(66), 1-12. [in Serbian: Veljković, B., Koprivica, R., Radivojević, D., Mileusnić, Z. (2015). Mleko i mlečni proizvodi u spoljnotrgovinskom bilansu Srbije].

14. Vlahović, B., Puškaš, A., Mugoša, I. (2018). Export of cheese from the Republic of Serbia - current state and perspective. Agroeconomics, 47(81), 59-70. [in Serbian: Vlahović, B., Puškaš, A., Mugoša, I. (2018). Izvoz sira iz Republike Srbije aktuelno stanje i perspektiva].

15. Zekić, S., Mijić, K., Jakšić, D., Milenković, I. (2016). Profitability gap in the milk production chain: Evidence from Serbia. Economics of Agriculture, 63(2), 485-499.

16. Zekić, V., Džinić, N., Tica, N., Tomović, V., Milić, D. (2015). Cost price determination for traditional meat products. Agroeconomics, 44(67), 117- 124. [in Serbian: Zekić, V., Džinić, N., Tica, N., Tomović, V., Milić, D. (2015). Utvrđivanje cene koštanja tradicionalnih proizvoda od mesa].

17. Zekić, V., Džinić, N., Tica, N., Tomović, V., Milić, D. (2016). Capacity utilization impact on the financial results of meat processing. Annals of Agronomy, 40(1), 95-99. [in Serbian: Zekić, V., Džinić, N., Tica, N., Tomović, V., Milić, D. (2016). Uticaj stepena korišćenja kapaciteta na finansijske rezultate u preradi mesa]. 